Published by LPMP Imperium

Journal homepage: https:/ / ejournal.imperiuminstitute.org/ index.php/ AKURASI

\title{
FAKTOR PENENTU HARGA SAHAM SEKTOR OTOMOTIF: PERAN KEBIJAKAN DIVIDEN, PROFITABILITAS, UKURAN PERUSAHAAN DAN GROWTH OPPORTUNITY
}

\author{
Oktavia Aqma Roza, Diyan Lestari* \\ Manajemen, Fakultas Bisnis, Institut Teknologi dan Bisnis Kalbis
}

\begin{abstract}
This study aims to analyze the effect of dividen policy, profitability, firm size and growth opportunity on stock prices in automotive companies during 2009-2017. This study was performed 13 automotive companies. The sampling technique that used in this research is purposive sampling method. This study has 8 companies. Data are analyzed by using panel regression and hypothesis test ( $\mathrm{t}$ statistic). The result showed that dividend policy do not effect the stock prices while profitability, firm size and growth opportunity had an effect on stock price.
\end{abstract}

\begin{abstract}
Abstrak
Penelitian ini bertujuan untuk mengetahui pengaruh kebijakan dividen, profitabilitas, ukuran perusahaan dan growth opportunity terhadap harga saham pada perusahaan otomotif periode 2009-2017. Penelitian ini dilakukam pada perusahaan otomotif sebanyak 13 perusahaan. Teknik pengambilan sampel yang digunakan dalam penelitian ini adalah metode purposive sampling. Sampel penelitian ini sebanyak 8 perusahaan. Data dianalisis menggunakan regresi panel dan uji hipotesis (statistik t). Hasil penelitian menunjukkan bahwa kebijakan dividen tidak berpengaruh terhadap harga saham sedangkan profitabilitas, ukuran perusahan dan growth opportunity berpengaruh terhadap harga saham.
\end{abstract}

Email korespondensi: diyan.lestari@kalbis.ac.id

Pedoman Sitasi: Oktavia Aqma Roza \& Diyan Lestari. (2020). FAKTOR PENENTU HARGA SAHAM SEKTOR OTOMOTIF: PERAN KEBIJAKAN DIVIDEN, PROFITABILITAS, UKURAN PERUSAHAAN DAN GROWTH OPPORTUNITY. AKURASI: Jurnal Riset Akuntansi dan Keuangan, 2(1), 29-40. DOI: https:/ / doi.org/ 10.36407/ akurasi.v2i1.160

\section{AKURASI}

29

Paper type

Accounting and finance,

Research paper

Received: 15 Feb 2020

Revised: 17 Mar 2020

Accepted: 25 Apr 2020

Online: 30 Apr 2020

Keywords: dividend policy, profitability, firm size, growth opportunity and stock price

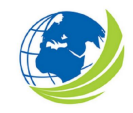

Akurasi: Jurnal Riset Akuntansi dan Keuangan, Vol 2, No.1, April 2020, pp. $29-40$

eISSN: 2685-2888 


\section{PENDAHULUAN}

Pertumbuhan ekonomi di Indonesia setiap tahunnya mengalami peningkatan, dengan perekonomian yang meningkat diharapkan dapat meningkat kesejahteraan masyarakat dan memudahkan perkembangan bisnis. selama 8 (delapan) tahun terakhir Indonesia mengalami pertumbuhan ekonomi yang fluktuatif pada kisaran 4 persen sampai dengan 6 persen. Pertumbuhan ekonomi yang cukup stabil diharapkan akan mendukung sebuah bisnis, akan tetapi hal itu juga dapat memunculkan persaingan bisnis Tidak ketinggalan pula perusahaan manufakur yang ikut meramaikan perkembangan ekonomi Indoneisa.Menurut Badan Pusat Statistik, apabila di lihat dari sisi pertumbuhan manufacturing value added (MVA), Indonesia menempati posisi tertinggi di antara negara-negara di ASEAN. MVA Indonesia mampu mencapai 4,84\% sedangkan di ASEAN berkisar 4,5\%. Di tingkat global, Indonesia saat ini berada di peringkat ke-9 dunia (Hartarto, 2018). data yang telah dirilis United Nations Statistic Division pada tahun 2016, Indonesia menempati peringkat keempat dunia dari 15 negara dengan PDB sebesar 22\%. Sejalan dari data Badan Pusat Statistik (2018) bahwa pertumbuhan manufaktur besar dan sedang mengalami kenaikan karena industri alat angkut naik sebesar 14,44\%. Hal tersebut menunjukkan bahwa sektor industri otomotif memberikan kontribusi yang cukup besar bagi perekonomian.

Menurut data Kemenperin (2018), industri otomotif menyumbang 10,16 persen di tahun 2017 pada Produk Domestik Bruto (PDB) serta mampu menyerap tenaga kerja langsung sekitar 350.000 orang dan tenaga kerja tidak langsung sebanyak 1,2 juta orang (Hartarto, 2018). Di Indonesia juga sedang berkembang masyarakat ekonomi kelas menengah yang ingin meningkatkan taraf kehidupannya, termasuk dalam berkendara. Terbukti dari data yang telah dirilis oleh Badan Pusat Statistik pertumbuhan kendaraan bermotor setiap tahun mengalami peningkatan, pada tahun 2016 BPS mencatat terdapat 14,5 juta kendaraan bermotor jenis mobil penumpang dan di tahun 2017 BPS mencatat terdapat 15,4 juta. Hal ini membuktikan bahwa pertumbuhan ekonomi kelas menengah akan meningkatkan industri otomotif. Dengan adanya peningkatan tersebut akan berdampak pada pergerakan harga saham.

Kebijakan dividen juga mempunyai pengaruh terhadap harga saham. Terdapat kecenderungan bahwa harga saham akan mengalami kenaikan bila terdapat pengumuman pembagian dividen. Kebijakan dividen menyangkut tentang masalah penggunaan laba yang menjadi hak para pemegang saham. Pada dasarnya, laba tersebut dibagikan atau ditahan untuk diinvestasikan kembali (Husnan dan Pudjiastuti, 2015). Investor akan menyukai adanya pembagian dividen, saat terjadi pengumuman pembagian dividen diharapkan harga saham akan meningkat tetapi pada saat perusahaan mengumumkan pembagian dividen harga saham pada $\mathrm{H}-3, \mathrm{H}-2$, dan $\mathrm{H}-$ 1 serta hari $\mathrm{H}$ cenderung mengalami penurunan hal ini disebabkan karna investor lebih tertarik dengan adanya cum dividend date sebab investor masih bisa mendapatkan dividen pada tanggal tersebut.

Harga saham juga dipengaruhi oleh profitabilitas, profitabilitas adalah rasio yang mengukur efektivitas manajemen secara keseluruhan yang ditunjukan oleh besar kecilnya tingkat keuntungan yang diperoleh dalam hubungannya dengan penjualan maupun investasi (Fahmi, 2014). Perusahaan dengan nilai ROA yang semakin tinggi mencerminkan kinerja yang baik dan akan direspon dengan harga saham yang semakin tinggi pula (Kumaidi dan Asandimitra, 2017). Faktor lain yang mempengaruhi harga saham selain kebijakan dividen dan profitabilitas adalah faktor ukuran perusahaan. Ukuran perusahaan adalah skala besar perusahaan yang ditentukan oleh beberapa hal antara lain total penjualan dan dari total aktiva atau harta (Putranto dan Darmawan, 2018). 
Berbagai studi sebelumnya telah banyak yang mengidentifikasi faktor-faktor yang dapat mempengaruhi harga saham, termasuk kebijakan dividen (Handayani, Indarti, \& Listiyowati, 2019; Istanti, 2018; Ulfah, Andini, \& Oemar, 2018; Agusta, Irdiana \& Taufik, 2018; Wijaya, 2017; Nugraha \& Sudaryanto, 2016); profitabilitas (Ramadhani, 2018; Rianto, 2018; Agusta, Irdiana \& Taufik, 2018); ukuran perusahaan (Ulfah, Andini, \& Oemar, 2018; Handayani et al., 2019; Wijaya, 2017). Meskipun sudah banyak diteliti, hasil studi sebelumnya masih memiliki perbedaan kesimpulan yang mengindikasikan bahwa tiga faktor tersebut masih perlu diklarifikasi ulang. Misalnya, Handayani et al. (2019) menemukan bahwa kebijakan dividen tidak berpengaruh terhadap harga saham, sedangkan ukuran perusahaan memiki efek negatif terhadap harga saham sektor manufaktur. Istanti (2018) dalam studinya menguji pengaruh kebijakan dividen terhadap harga saham pada perusahaan LQ 45 memberikan kesimpulan bahwa kebijakan dividen bukan satu-satunya faktor yang mempengaruhi harga saham, tetapi ada faktor lain yang mempengaruhi, yaitu faktor makro dan mikro ekonomi. Kesimpulan yang sama juga dinyatakan oleh Agusta et al. (2018) yang tidak berhasil membuktikan pengaruh kebijakan dividen terhadap harga saham. Namun studi Wijaya (2017) memberikan kesimpulan berbeda dimana dividend payout memiliki efek positif pada harga saham.

Terkait dengan profitabilitas, Rianto (2018) meneliti di sektor property menemukan bahwa profitabilitas yang diproxy kan dengan ROE berpengaruh signifikan terhadap return saham. Hal serupa juga dibuktikan oleh Ulfah et al. (2018) dan Agusta et al. (2018) yang membuktikan efek signifikan ROA terhadap harga saham. Hasil berbeda ditemukan oleh Suhadi (2019) yang menemukan bahwa profitabilitas (ROA) tidak signifikan mempengaruhi industri manufaktur makanan dan minuman. Tidak konsitennya temuan ini menunjukkan bahwa upaya untuk menjelaskan pengaruh profitabilitas terhadap harga saham masih perlu dilakukan.

Sejalan dengan kebijakan dividen dan profitabilitas, hubungan antara ukuran perusahaan dengan harga saham juga masih perlu diklarifikasi ulang. Beberapa studi seperti Handayani et al. (2019) dan Ulfah et al. (2018) menemukan efek signifikan ukuran perusahaan ke harga saham. Namun studi Suryandani (2018) menyebutkan bahwa ukuran perusahaan tidak berpengaruh terhadap nilai perusahaan. Penelitian ini ditujukan untuk melakukan pengujian ulang pada model hubungan kebijakan dividen, profitablitas, ukuran perusahaan, dan pertumbuhan terhadap harga saham di sektor otomotif. Hasil studi diharapkan dapat memberikan bukti empiris terbaru sekaligus menjadi informasi yang bermanfaat untuk para investor untuk mengevaluasi kebijakan investasi melalui faktor fundamental perusahaan, khususnya di sektor otomotif.

\section{KAJIAN PUSTAKA}

\section{Landasan teoritis}

Signaling theory adalah perilaku manajemen perusahaan dalam memberikan arahan kepada investor, terkait dengan strategi manajemen dan pandangan tentang prospek masa depan (Brigham \& Houston, 2011). Pengungkapan teori pensinyalan adalah dalam bentuk informasi (sinyal) keberhasilan atau kegagalan suatu perusahaan. Teori pensinyalan juga menyatakan bahwa perusahaan yang berkualitas baik akan dengan sengaja memberi sinyal kepada pasar, sehingga pasar diharapkan dapat membedakan perusahaan yang berkualitas baik dan buruk. Agar sinyal menjadi baik maka harus ditangkap dan dirasakan pasar yang baik dan tidak mudah ditiru oleh perusahaan yang memiliki kualitas buruk. Sinyal yang baik dapat ditangkap oleh pasar dan tidak mudah ditiru oleh perusahaan-perusahaan berkualitas rendah adalah implementasi teori pensinyalan yang mendasari praktik perataan laba, salah satu bentuk manajemen pendapatan.

Teori signal berkaitan dengan informasi asimetris yang dapat terjadi jika salah satu pihak memiliki sinyal informasi yang lebih lengkap daripada pihak lain. Angka-angka akuntansi yang dilaporkan oleh manajemen dapat digunakan sebagai sinyal, jika angka-angka tersebut dapat mencerminkan informasi tentang atribut keputusan perusahaan yang tidak dimonitor. Selain informasi 
laporan keuangan yang terkadang menunjukkan hasil manipulasi laba, investor juga mempertimbangkan laporan keberlanjutan sebagai sinyal informasi yang andal (Kim et al., 2014; Harmadji et al., 2018).

Pengaruh Kebijakan Dividen terhadap Harga Saham

Kebijakan dividen menyangkut tentang masalah penggunaan laba yang menjadi hak para pemegang saham. Pada dasarnya, laba tersebut dibagikan atau ditahan untuk di investasikan kembali (Husnan dan Pudjiastuti, 2015: 309). Kebijakan dividen mempunyai hubungan terhadap harga saham. Hal ini dapat dilihat dari pembagian dividennya. Terdapat kecenderungan bahwa harga saham akan mengalami kenaikan apabila terdapat pengumuman dividen. Besarnya dividen yang akan dibayarkan tergantung dari masing-masing perusahaan. Jika dividen yang dibagikan besar maka akan meningkatkan harga saham. Pernyataan tersebut sejalan dengan beberapa penelitian seperti pada penelitian Nugraha dan Sudaryanto (2016) dengan hasil penelitian bahwa dividend payout ratioberpengaruh positif signifikan terhadap harga saham. DPR berpengaruh positif maka dapat dinyatakan bahwa setiap kenaikan DPR juga akan diikuti oleh peningkatan harga saham. Sehingga memiliki hipotesis berupa:

$\mathrm{H}_{1}$ : kebijakan dividen berpengaruh terhadap harga saham

Pengaruh Profitabilitas terhadap Harga Saham

Profitabilitas adalah rasio yang mengukur efektivitas manajemen secara keseluruhan yang ditunjukkan dengan penjualan maupun investasi (Fahmi, 2014: 80-82). Profitabilitas dalam penelitian ini akan diproksikan dengan return on asset (ROA), return on asset akan melihat sejauh mana investasi yang telah ditanamkan mampu memberikan pengembalian keuntungan yang diharapkan. Menurut Zaki et al (2017: 60) ROA yang positif menujukkan bahwa dari total aktiva yang dipergunakan perusahaan untuk beroperasi, mampu memberikan laba bagi perusahaan, sebaliknya jika ROA negatif menunjukkan bahwa dari total aktiva yang digunakan perusahaan mengalami kerugian. Tujuan utama sebuah perusahaan adalah untuk menghasilkan tingkat profitabilitas yang maksimal. Terdapat berbagai macam rasio profitabilitas salah satu adalah Return On Assets (ROA) yaitu rasio yang menunjukkan kemampuan dari seluruh aset yang dimiliki dan digunakan untuk menghasilkan keuntungan. Perusahaan dengan ROA yang semakin tinggi maka dipersepsikan memiliki kinerja yang lebih baik dibandingkan tahun sebelumnya dengan kinerja yang semakin baik maka akan menciptakan harga saham yang semakin tinggi juga (Kumaidi dan Asandimitra, 2017). Sehingga memiliki hipotesis berupa:

$\mathrm{H}_{2}$ : profitabilitas berpengaruh terhadap harga saham.

Pengaruh Ukuran Perusahaan terhadap Harga Saham

Perusahaan dengan skala atau ukuran yang lebih besar diproyeksikan mampu menjalankan usahanya dengan lebih efektif dan efisien, terutama terkait dengan pengelolaan terhadap keuangannya sehingga akan meningkatkan harga sahamnya dibandingkan dengan perusahaan yang memiliki skala lebih kecil. Hal ini sebanding dengan penyataan Putranto dan Darmawan (2018: 110) ukuran perusahaan memiliki dampak terhadap harga saham dengan cara positif. Serta hasil penelitian dari Zaki et al (2017 memiliki hasil rasio ukuran perusahaan yang diukur dengan logaritma natural dari total assets secara parsial berpengaruh signifikan terhadap harga saham. Sehingga memiliki hipotesis berupa:

$\mathrm{H}_{3}$ : ukuran perusahaan berpengaruh terhadap harga saham.

Pengaruh growth opportunity terhadap Harga Saham

Peluang pertumbuhan atau growth opportunity merupakan peluang atau kesempatan suatu perusahaan untuk terus tumbuh di masa yang akan datang. Menurut Fidhayatin dan Dewi (2012: 204) tingkat pertumbuhan yang tinggi akan pada suatu perusahaan ditandai dengan adanya tingkat kesempatan investasi tinggi yang dilakukan oleh perusahaan. Pertumbuhan perusahaan yang baik akan semakin 
menigkatkan kepercayaan pihak eksternal terhadap perusahaan dengan begitu pihak luar atau eksternal akan membeli saham. Hal ini akan memiliki dampak terhadap peningkatan harga saham, jika permintaan saham di masyarakat meningkat. Sejalan dengan penelitian Sukarno et al (2016) yang menyatakan bahwa pertumbuhan perusahaan memiliki pengaruh positif terhadap harga saham. Sehingga memiliki hipotesis berupa:

$\mathrm{H}_{4}$ : growth opportunity berpengaruh terhadap harga saham

\section{METODE PENELITIAN}

Desain penelitian

Penelitian ini menggunakan pendekatan kuantitatif dengan cara mengolah angka-angka sebagai bahan analisis dan diambil kesimpulannya untuk menjawab hipotesis. Penelitian kuantitatif biasanya dikaitkan dengan pendekatan deduktif, di mana fokusnya adalah pada penggunaan data untuk menguji teori. Namun, mungkin juga memasukkan pendekatan induktif, di mana data digunakan untuk mengembangkan teori (Hendryadi et al., 2019). Pengambilan data menggunakan pendekatan data panel yaitu gabungan antara cross-sectional (perusahaan otomotif) dan time series (pada periode waktu tertentu).

\section{Prosedur sampel}

Sampel adalah wakil semua unit strata dan sebagainya yang ada di dalam populasi (Bungin, 2014: 112). Sampel penelitian ini diambil dengan menggunakan purposive sampling yang mana lebih mengutamakan tujuan penelitian dari pada sifat populasi dalam menentukan sampel penelitian, dengan kriteria sebagai berikut: (1) perusahaan yang menjadi objek penelitian adalah perusahaan manufaktur aneka industri pada sub sektor otomotif \& komponen yang terdaftar di dalam Bursa Efek Indonesia selama periode 2009-2017; (2) Perusahaan otomotif \& komponen yang terdaftar secara konsisten di dalam Bursa Efek Indonesia periode 2009-2017; (3) Perusahaan otomotif \& komponen yang tidak konsisten terdaftar di dalam Bursa Efek Indonesia periode 2009-2017; dan (4) Perusahaan otomotif \& komponen yang membagikan dividen serta mengeluarkan laporan tahunan tidak lengkap selama periode 2009-2017.

Pengukuran variabel

Pengukuran variabel mengadaptasi pendapat dan studi sebelumnya. Harga saham adalah harga selembar saham yang terjadi pada saat tertentu serta harganya ditentukan oleh permintaan dan penawaran di pasar modal (Kumaidi dan Asandimitra, 2017).

Harga Saham $=$ closing prices pada 31 desember

Kebijakan dividen di proksikan dengan dividen payout ratio, dividen payout ratio adalah cara untuk menentukan perbandingan antara dividen tunai terhadap laba per saham atau earning per share, dengan rumus (Samsul, 2015: 175)

$$
\text { Dividen Payout Ratio }=\frac{\text { Cash Dividend }}{\text { Earning Per Share }}
$$

Return on Asset dapat dirumuskan dengan pendapatan bersih sudah pajak terhadap total asset (Fahmi, 2014).

$R O A=\frac{\text { Earning After } \operatorname{Tax}(E A T)}{\text { Total Assets }} \times 100 \%$ 
Penentuan ukuran perusahaan dapat di hitung melalui logaritma natural dari total aset atau aktiva, total aset dijadikan indikator ukuran perusahaan karena sifatnya jangka panjang dibandingkan dengan penjualan (Alviansyah et al, 2018).

\section{Ukuran Perusahaan $=\operatorname{Ln} \times$ Total Assets}

Pertumbuhan perusahaan dapat di ukur dengan menggunakan rumus Tobin's Q seperti yang terdapat di dalam penelitian (Sindhu, Hashmi dan Haq, 2016).

Tobin's $Q=\frac{\text { market value of equity }+ \text { liability }}{\text { total assets }}$

Teknik analisis

Teknik analisis yang digunakan adalah regresi data panel dengan bantuan program EVIEWS.

\section{HASIL DAN PEMBAHASAN}

Penelitian ini dilakukan untuk mengetahui pengaruh kebijakan dividen, profitabilitas, ukuran perusahaan dan growth opportunity terhadap harga saham perusahaan otomotif periode 2009-2017. Penelitian ini menggunakan data sekunder dari website IDX (www.idx.co.id). Pengambilan sampel penelitian digunakan metode purposive sampling.

\section{Statistik Deskriptif}

Pengolahan data pada penelitian ini berupa data harga saham yang bersumber dari situs dunia investasi(www.duniainvestasi.com), dividen payout ratio (DPR), return on assets (ROA), ukuran perusahaan (Size) serta growth opportunity yang bersumber dari laporan keuangan tahunan pada situs Bursa Efek Indonesia (www.idx.co.id). Data-data tersebut diolah dengan menggunakan program EViews versi 10.

Harga saham memiliki nilai maximum 8300 pada PT Astra Internasional Tbk di tahun 2017 dan data minimum 205 pada PT Multisrada Arah Sarana Tbk di tahun 2009. 2. DPR memiliki nilai minimum sebesar -0,590 pada PT Indomobil Sukses Makmur Tbk di tahun 2015 karena memiliki net income rugi tetapi masih tetap membagikan dividen sehingga dividend payout ratio yang dipeoleh menjadi negatif dan data maximum sebesar 0.950 pada PT Gajah Tunggal Tbk di tahun 2010. ROA jmemiliki nilai maximum sebesar 0.240 pada PT Selamet Sempurna tbk di tahun 2014 dan nilai minimum sebesar 0,020 pada PT Gajah Tunggal Tbk di tahun 2015 karena memperoleh net income negatif atau rugi sehingga diperoleh nilai ROA yang negatif. Ukuran perusahaan memiliki nilai maximum sebesar 33,00 pada PT Astra Internasional Tbk di tahun 2011,2012, 2013, 2014, 2016 dan 2017 serta nilai minimum sebesar 25,00 pada PT Multisrada Arah Sarana di tahun 2017. Growth opportunity juga memiliki nilai maximum sebesar 23,360 pada PT multisrada Arah Sarana di tahun 2011 dan juga nilai minimum sebesar 0,450 pada PT Indospring Tbk di tahun 2015 dan 2016.

\section{Uji Metode Estimasi Model Regresi Panel}

Uji Chow

Uji chow digunakan untuk memilih model yang paling sesuai antara Fixed Effects dan Common Effects. Tabel 1 menunjukkan nilai probabilitas cross-section $\mathrm{F}$ dan cross-section chi-square adalah 0.0000 , sehingga model yang dipilih adalah Fixed Effects. 
AKURASI, 2(1), 29-40

Oktavia Aqma Roza \& Diyan Lestari, dividend policy, profitability, firm size...

Tabel 1. Hasil Uji Chow

Redundant Fixed Effects Tests

Equation: Untitled

Test cross-section fixed effects

\begin{tabular}{llll}
\hline \hline Effects test & Statistic & d.f. & Prob. \\
\hline Cross-section F & 10.578360 & $(7,60)$ & 0.0000 \\
\hline Cross-section Chi-square & 57.877723 & 7 & 0.0000 \\
\hline \hline
\end{tabular}

Sumber: data diolah (2019).

Uji hausman

Uji hausman juga digunakan untuk menentukan model yang paling sesuai antara Fixed Effects atau Random Effects. Nilai probabilitas crossection random sebesar 0,7363 lebih besar daripada 0,05. Sehingga dapat disimpulkan lebih baik menggunakan model Random Effects dalam penelitian ini.

Tabel 2. Hasil Uji Hausman

Correlated Random Effects - Hausman Test

Equation: Untitled

Test cross-section random effects

\begin{tabular}{lcll}
\hline \hline Test Summary & $\begin{array}{l}\text { Chi-Sq. } \\
\text { Statistic }\end{array}$ & $\begin{array}{l}\text { Chi- } \\
\text { Sq. d.f. }\end{array}$ & Prob \\
\hline Crosssection random & 1.996980 & 4 & 0.7363 \\
\hline \hline
\end{tabular}

Sumber: data diolah (2019).

Uji Lagrange Multiplier

Uji lagrange multiplier digunakan untuk menentukan model common effects atau random effects yang paling sesuai. Nilai probabilitas chi-square sebesar 0.0000 lebih kecil dari 0.05 sehingga dapat disimpulkan bahwa lebih baik menggunakan model random effects dalam penelitian ini.

Tabel 3. Hasil Uji Lagranger Multiplier

Lagrange Multiplier Tests for Random Effects

Null hypotheses: No effects

Alternative hypotheses: Two-sided (Breusch-Pagan) and one-sided

(all others) alternative

\begin{tabular}{llll}
\hline \hline \multicolumn{4}{l}{ Test Hypothesis } \\
& $\begin{array}{l}\text { Cross- } \\
\text { section }\end{array}$ & Time & Both \\
\hline \hline Breusch-Pagan & 54.59995 & 0.038961 & 54.63891 \\
& $(0.0000)$ & $(0.8435)$ & $(0.0000)$ \\
\hline
\end{tabular}

Sumber: data diolah (2019).

Dari ketiga uji model regresi panel yang telah dilakukan, dapat diambil kesimpulan bahwa hasil uji pada penelitian ini menggunakan metode random effects. 
Persamaan Regresi Liniear Berganda

Hasil analisis regresi data panel ditampilkan pada Tabel 4 berikut ini:

Tabel 4. Hasil Uji Regresi Liniear Berganda

\begin{tabular}{llll}
\hline Variabel & Koefisien & t-statistik & Prob \\
\hline C & -21856.4 & -5.5346 & 0.000 \\
DPR & 1285.860 & 1.5579 & 0.124 \\
ROA & 9530.373 & 2.6700 & 0.009 \\
SIZE & 767.7846 & 6.0562 & 0.000 \\
GROWTH & 262.010 & 4.2012 & 0.000 \\
Adj. R Square & 0.3459 & & \\
F-Statistics & 10.3876 & & \\
Prob & 0.000 & & \\
\hline
\end{tabular}

Sumber: data diolah (2019).

Harga $=-21856.41+1285.860$ DPR +9530.373 ROA + 767.7846 SIZE + 262.0104 GROWTH +e

Dari persamaan di atas maka akan memberikan kesimpulan sebagai berikut: Persamaan harga saham memiliki nilai konstanta sebesar -21856.41, hal ini menyatakan bahwa variabel kebijakan dividen, profitabilitas, ukuran perusahaan dan juga growth opportunity memiliki nilai 0 (nol), maka harga saham akan memiliki nilai awal sebesar -21856,41. Variabel kebijakan dividen yang di proksikan dengan dividend payout ratio (DPR) memiliki jumlah koefisien yang positif dengan harga saham. Sehingga dapat diasumsikan bahwa variabel tersebut adalah tetap, setiap kenaikan 1 nilai dividen payout ratio maka akan meningkatkan nilai harga saham sebesar 1285,860.

Variabel ROA memiliki jumlah koefisien yang positif terhadap harga saham dengan nilai koefisien regresi sebesar 9530.373 menyatakan bahwa setiap kenaikan 1 nilai ROA maka akan meningkatkan nilai harga saham sebesar 9530,373. Variabel ukuran perusahaan (size) juga memiliki jumlah koefisien positif terhadap harga saham. Dapat diasumsikan bahwa variabel adalah tetap, setiap kenaikan 1 nilai ukuran perusahaan maka akan meningkatkan nilai harga saham sebesar 767,7846. Variabel growth opportunity memiliki jumlah koefisien positif terhadap harga saham dengan nilai koefisien regresi 262,0104 menyatakan bahwa setiap kenaikan 1 nilai growth maka akan meningkatkan nilai harga saham sebesar 262,0104.

Pembahasan

Hasil analisis menunjukkan bahwa dari empat hipotesis yang diajukan, tiga hipotesis terdukung dan satu hipotesis tidak terdukung secara statistik. Pertama, kebijakan dividen dalam studi ini tidak terbukti signifikan mempengaruhi harga saham. Dengan demikian dapat dinyatakan bahwa harga saham tidak akan terpengaruh dengan kebijakan dividen yang dilakukan perusahaan, khususnya sektor otomotif. Kebijakan dividen menyangkut penggunaan laba yang menjadi hak para pemegang saham. Pada dasarnya, laba tersebut dibagikan atau ditahan untuk diinvestasikan kembali (Husnan dan Pudjiastuti, 2015). Studi ini mendukung hasil penelitian Handayani et al. (2019), Istanti (2018), dan Agusta et al. (2018) yang juga tidak berhasil membuktikan efek kebijakan dividen terhadap harga saham. Penjelasan logis dari temuan ini adalah harga saham tidak akan secara langsung terkoreksi atas kebijakan dividen yang diambil perusahaan, sehingga perlu untuk menguji efek jangka panjang kebijakan dividen terhadap harga saham.

Berikutnya, profitabilitas, ukuran perusahaan, dan peluang pertumbuhan secara signifikan dapat mempengaruhi variasi harga saham. Hal ini mengindikasikan bahwa ketiga faktor ini dapat dijadikan sebagai determinan harga saham sektor otomotif sehingga dapat dijadikan informasi yang bermanfaat 
bagi investor dalam upaya memilih saham yang dianggap prospektif, terutama dari sisi capital gain. Studi ini mendukung temuan Rianto (2018) yang meneliti di sektor property menemukan bahwa profitabilitas yang diproxy kan dengan ROE berpengaruh signifikan terhadap return saham. Hal serupa juga dibuktikan oleh Ulfah et al. (2018) dan Agusta et al. (2018) yang membuktikan efek signifikan ROA terhadap harga saham. Beberapa studi lain yang berhasil didukung adalah Handayani et al. (2019) dan Ulfah et al. (2018) yang menemukan efek signifikan ukuran perusahaan ke harga saham. Kesempatan bertumbuh dalam studi ini juga berhasil dibuktikan memiliki efek signifikan terhadap harga saham. Oleh karenanya dapat dinyatakan bahwa jika investor menilai bahwa perusahaan memiliki tingkat pertumbuhan yang baik maka permintaan dan harga saham tersebut akan meningkat. Hasil ini sejalan dengan Sukarno et al (2016) yang menyatakan bahwa pertumbuhan perusahaan memiliki pengaruh positif terhadap harga saham

\section{KESIMPULAN}

Penelitian ini bertujuan untuk mengevaluasi determinan harga saham berdasarkan kebijakan dividen, profitabilitas, ukuran perusahaan dan peluang pertumbuhan pada perusahaan sektor otomotif yang terdaftar di Bursa Efek Indonesia. Berdasarkan hasil analisisi diperoleh kesimpulan bahwa kebijakan dividen tidak terbukti signifikan mempengaruhi harga saham, sedangkan profitabilitas, ukuran perusahaan, dan peluang pertumbuhan secara signifikan dapat mempengaruhi variasi harga saham.

Implikasi

Berdasarkan simpulan penelitian, maka implikasi manajerial dari penelitian ini adalah: pertama, harga saham menjadi salah satu faktor yang menjadi pertimbangan investor untuk melakukan penanaman modalnya pada perusahaan tersebut. Harga saham yang tinggi diharapkan mampu membuat investor untuk mendapatkan keuntungan yang tinggi pula hal tersebut mencerminkan return dan kekayaan investor. Untuk mendapatkan harga saham yang tinggi hal berkaitan dengan kebijakan dividen, maka perusahaan harus meningkatkan penjuala dan juga perusahaan tidak perlu membagikan dividen jika mengalami kerugian.

Kedua, agar harga saham meningkat atau tetap terjaga dengan baik terkait dengan profitabilitas yang diproksikan dengan return on assets maka hal yang perlu dilakukan perusahaan adalah dengan meningkatkan penjualan secara maksimal sehingga mendapatkan keuntungan yang maksimal juga. Serta perusahaan dapat mengurangi beban. Ketiga, untuk menjaga kestabilan dari harga saham terkait dengan ukuran perusahaan hal yang pelu dilakukan oleh perusahaan adalah dengan memaksimalkan total assets yang dimiliki sehingga dapat menunjang operasional perusahaan dalam menghasilkan laba, karena dengan adanya pertumbuhan serta dapat menjaga dan meningkatkan total assets dengan tujuan untuk menunjang kegiatan operasional perusahaan sehingga tujuan perusahaan dapat tercapai dan dapat menarik minat investor untuk berinvestasi. Terakhir, untuk menjaga peluang pertumbuhan terkait dengan harga saham agar tetap dapat terjaga dan terus naik maka hal yang harus dilakukan oleh perusahaan dengan meningkatkan market value dan mengurangi beban operasional.

\section{Keterbatasan}

Penelitian ini tentu mengalami keterbatasan antara lain: pertama, hanya meneliti variabel kebijakan dividen, profitabilitas, ukuran perusahaan dan growth opportunity. Peneliti tidak memasukkan variabel lain di dalam penelitian ini. Kedua, populasi penelitian ini adalah perusahaan otomotif yang terdaftar di Bursa Efek Indonesia (BEI), dengan sampel penelitian perusahaan yang membagikan dividen pada periode 2009-2017. Sehingga peneliti tidak meneliti perusahaan yang tidak membagikan dividen. Ketiga, periode penelitian ini hanya dilakukan dari tahun 2009-2017, hal ini dikarenakan keterbatasan data yang mampu di dapatkan oleh peneliti. Berdasarkan keterbatasan tersebut maka studi mendatang perlu menambahkan variabel lain yang diperkirakan dapat mempengaruhi harga saham seperti hutang, tata kelola, atau faktor makro ekonomi dari sisi eksternal perusahaan. Selain itu, studi berikutnya perlu 
mengembangkan sampel yang lebih besar, mengambil berbagai sektor, dan memperpanjang periode pengamatan sehingga hasil penelitian lebih dapat digeneralisasi.

\section{REFERENSI}

Agusta, R. B., Irdiana, S., \& Taufik, M. (2018). Profitabilitas, Struktur Modal, Kebijakan Dividen Pengaruhnya Terhadap Harga Saham Perusahaan. Jobman: Journal of Organization and Bussines Management, 1(2), 101-108.

Badan Pusat Statistik. (2018).Pertumbuhan Ekonomi Indonesia.[Online]. Diakses pada tanggal 1 Maret 2019 dari https:/ / www.bps.gp.id/ pressrelease/ 2018/ 02/ 05/ 1519/ ekonomi-indonesiatriwulan-iv-2017-tumbuh-5-19-persen.html

Badan Pusat Statistik. (2018). Pertumbuhan Produksi Industri Manufaktur Triwulan IV-2017.[Online]. $\begin{array}{llllll}\text { Diakses } & \text { pada } & \text { tanggal } & 1 & \text { Maret } & 2019\end{array}$ https:/ / www.bps.go.id/ pressrelease/ 2018/ 02/ 01/ 1479/ pertumbuhan-produksi-industrimanufaktur-besar-dan-sedang-triwulan-iv-tahun-2017-naik-sebesar-5-15-persen-danpertumbuhan-produksi-industri-manufaktur-mikro-dan-kecil-triwulan-iv-2017-naik-sebesar-459-pe

Brigham, E. F. and Houston, J. F. (2011). Dasar-dasar Manajemen Keuangan (A. A.Yulianto (ed.) (eleventh edition). Jakarta: Salemba Empat

Bungin, B. (2014). Metodologi Penelitian Kuantitatif: Komunikasi, Ekonomi dan Kebijakan Publik Serta Ilmu-Ilmu Sosial Lainnya Edisi Kedua. Jakarta: Kencana Prenadamedia Group.

Fidhayatin, S. K., \& Dewi, N. H. (2012). Analisis Nlai Perusahaan, Kinerja Perusahaan Dan Kesempatan Bertumbuh Perusahaan Terhadap Return Saham Pada Perusahaan Manufaktur Yang Listing Di BEI". The Indonesian Accounting Review, 2(2), 203-214.

Ghozali, I., \& Ratmono, D. (2017). Analisis Multivariat Dan Ekonometrika Teori, Konsep, Dan Aplikasi Dengan Eviews 10. Semarang: Badan Penerbit Universitas Diponegoro.

Handayani, K. M., Indarti, I., \& Listiyowati, L. (2019). Pengaruh Kinerja Keuangan dan Ukuran Perusahaan terhadap Harga Saham dengan Kebijakan Dividen sebagai Variabel Intervening pada Perusahaan Manufaktur yang Terdaftar di Bursa Efek Indonesia. Jurnal Ilmiah Aset, 21(2), 93-105.

Harmadji, D. E., Subroto, B., Saraswati, E., \& Prihatiningtias, Y. W. (2018). From Theory to Practice of Signaling Theory: Sustainability Reporting Strategy Impact on Stock Price Crash Risk with Sustainability Reporting Quality as Mediating Variable. KnE Social Sciences.

Hartarto, A. (2018). Menperin: indusrti otomotif berkontribusi 10,16\% pada prekonomian nasional. [Online]. Diakses pada tanggal 17 April 2019 dari https:/ / industri.kontan.co.id/ news/ menperinindusrti-otomotif-berkontribusi-1016-pada-perekonomian-nasional

Hartarto, A. (2018). Pertumbuhan Nilai Tambah Manufaktur Indonesia Teringgi di ASEAN. [Online]. Diakses pada tanggal $4 \quad$ Maret 2019 dari https:/ / economy.okezone.com/ read/ 2018/ 02/ 11/ 320/ 1858006/ pertumbuhan-nilai-tambahmanufaktur-indonesia-tertinggi-di asean

Hendryadi, H., Tricahyadinata, I., \& Zannati, R. (2019). Metode Penelitian: Pedoman Penelitian Bisnis dan Akademik. Jakarta: LPMP Imperium.

Husnan, S., \& Pudjiastuti, E. (2015). Dasar-Dasar Manajemen Keuangan Edisi Ketujuh. Yogyakarta: UPP STIMYKPN.

Istanti, S. L. W. (2018). Pengaruh Kebijakan Dividen Terhadap Harga Saham pada Perusahaan LQ 45. potensio, 19(01).

Katadata.co.id. (2018). [Online]. Diakses pada tanggal 16 Juni 2019 dari https:/ / databoks.katadata.co.id/ datapublish/2018/ 07/ 23/ berapa-nilai-ekspor-mobil-indonesia

Kementerian Perindustrian. (2019). Kontribusi Industri Manufaktur Indonesia Peringkat Keempat Duni". [Online]. Diakses pada tanggal 1 Maret 2019 dari 
Oktavia Aqma Roza \& Diyan Lestari, dividend policy, profitability, firm size...

https:// www.kemenperin.go.id/ artikel/ 18325/ Kontribusi Industri-Manufaktur-IndonesiaPeringkat-Keempat-Dunia

Kim, Y., Li, H., and Li, S. (2014). Corporate social responsibility and stock price crash risk. Journal of Banking \& Finance, 43, 1-13

Kumaidi, R. K., \& Asandimitra, N. (2017). Pengaruh ROA, ROE, DER, DPR, Dan LDR Terhadap Harga Saham Sektor Perbankan BEI Periode 2011 - 2016 (Dengan Penggolongan Kapitalisasi Kecil dan Kapitalisasi Besar ). Jurnal Ilmu Manajemen, 5(3) , 1-13.

Nugraha, R. D., \& Sudaryanto, B. (2016). "Analisis Pengaruh DPR, DER, ROE, Dan TATO Terhadap Harga Saham (Studi Kasus pada Perusahaan Industri Dasar dan Kimia yang Terdaftar di BEI Periode 2010-2014)". Diponegoro Journal Of Management, 5(4), 1-12.

Putranto, A. D., \& Darmawan, A. (2018). Pengaruh Ukuran Perusahaan, Profotabilitas, Leverage, Dan Nilai Pasar Terhadap Harga Saham ( Studi Kasus pada Perusahaan Pertambangan yang Terdaftar di Bursa Efek Indonesia Periode 2010-2016). Jurnal Administrasi Bisnis (JAB), 56(1), 110-117.

Ramadhani, I. (2018). Pengaruh profitabilitas, likuiditas, solvabilitas terhadap harga saham. Jurnal Manajemen Strategi Dan Aplikasi Bisnis, 1(1), 59

Rianto, M. R. (2018). Implikasi Return on Equity, Return on Asset, Net Income\& Debt to Equity Ratio Terhadap Return Saham Pada Perusahaan Properti. Jurnal Riset Manajemen dan Bisnis (JRMB) Fakultas Ekonomi UNIAT, 3(1), 59-66.

Samsul, M. (2015). Pasar Modal Dan Manajemen Portofolio. Jakarta: Erlangga.

Sindhu, M. I., Hashmi, S. H., \& Haq, E. U. (2016). Impact of ownership structure on dividend payout ratio in Pakistani non-financial sector. Cogent Business \& Management, 1-11.

Suryandani, A. (2018). PENGARUH PERTUMBUHAN PERUSAHAAN, UKURAN PERUSAHAAN, DAN KEPUTUSAN INVESTASI TERHADAP NILAI PERUSAHAAN PADA PERUSAHAAN SEKTOR PROPERTY DAN REAL ESTATE DI BEI. Business Management Analysis Journal (BMAJ), 1(1), 49-59.

Suhadi, D. (2019). Pengaruh Rasio Aktivitas, Rasio Profitabilitas, Rasio Laverage, dan Rasio Penilaian Terhadap Harga Saham Perusahaan Food and Beverage. Jurnal Informasi, Perpajakan, Akuntansi, dan Keuangan Publik, 4(1), 17-35.

Ulfah, E., Andini, R., \& Oemar, A. (2018). Pengaruh CR, DER, ROA dan Ukuran Perusahaan Terhadap Harga Saham Dengan Kebijakan Dividen Sebagai Variabel Intervening. Journal Of Accounting, 4(4).

Zaki, M., Islahuddin, \& Shabri, M. (2017). Pengaruh Profitabilitas, Leverage Keuangan Dan Ukuran Perusahaan Terhadap Harga Saham (Studi Pada Perusahaan Manufaktur Yang Terdaftar Di Bursa Efek Indonesia Periode 2005-2014). Jurnal Megister Akuntansi, 6(2), 58-66.

Wijaya, R. (2017). Kinerja keuangan dan ukuran perusahaan terhadap harga saham dengan kebijakan dividen sebagai variabel intervening.Jurnal Keuangan dan Perbankan, 21(3), 196434.

www.duniainvestasi.com (Diakses 1 Maret 2019)

www.idx.co.id (Diakses 22 Februari 2019)

\section{PROFIL PENULIS}

Oktavia Aqma Roza dan Diyan Lestari adalah mahasiswa dan dosen di Prodi Manajemen, Fakultas Bisnis, Institut Teknologi dan Bisnis Kalbis 
AKURASI: Jurnal Riset Akuntansi dan Keuangan

Vol 2, No. 1, April 2020

Published by LPMP Imperium

Akurasi: Jurnal Riset Akuntansi dan Keuangan, Vol 2, No.1, April 2020, pp. $29-40$ eISSN: 2685-2888

Journal homepage: https:/ / ejournal.imperiuminstitute.org/index.php/ AKURASI 